Mr. Fergusson proposed the "Provincial Schools of England ;" a toast which was received with acclamation. Alluding to the results of the election that day, he congratulated the Fellows on the "marvellous" freedom with which they had exercised their electoral franchise.

Mr. Samuel Smirm briefly acknowledged the toast, and proposed the "Metropolitan Schools," coupling therewith Mr. Paget.

Mr. PAGET, who, on rising, was received with repeated rounds of applause, proceeded, when silence was restored, to endorse the views of the College Council respecting medical education; remarking that, in his experience, the most skilful and successful practitioners are those who commenced their professional education by gaining some preliminary practical knowledge, rather than by directly going to places and among those where the language of medicine is too fluently spoken. In concluding an able spcech, Mr. Paget passed an earnest and eloquent eulogy on the merits of the worthy chairman.

Mr. TURNer acknowledged with much feeling the compliment paid him by one whose judgment and good opinion he so much valued. He then dwelt with thankfulness on the reciprocity of feeling existing between the Provincial and the $\mathrm{Me}$. tropolitan Schools. (Applause.)

"The Medical Benevolent Fund," coupled with Mr. Toynbee, was duly responded to.

Mr. CALLENDER acknowledged the unanimous thanks of the meeting for his services as honorary secretary.

The dinner gave general satisfaction, and the utmost cordiality prevailed.

\section{MEETING OF THE MEDICAL PRACTITIONERS OF BEDFORD AND ITS NEIGHBOURHOOD.}

A MeETING was held at the George Hotel on the 6th inst., at two o'clock. Mr. Couchman, Mayor of the Borough, was called to the chair, and the following gentlemen were present:-Dr. Barker, Mr. Carter, Mr. Goldsmith, Mr. Hacon, Dr. Harris, Dr. Prior, Mr. G. Robinson, Mr. Sharpin, Dr. Sprigge, Mr. Stedman, Mr. Thurnall, Mr. Williams, and (at a later period of the meeting) Mr. Coombs.

Dr. PRIOI explained the circumstances which called for this meeting-namely, the correspondence in THE LAFCET relating to the fact that Dr. Burrows and Dr. Wharton had met in consultation with Mr. Coombs, the fact that Mr. Coombs had never given a satisfactory disavowal of the practise of homcepathy, and that Dr. Wharton still continued to meet him in consultation. Mr. Coombs having privately stated that he does not practise homœopathy, and having intimated his willingness to give any pledge required of him for the future.

Resolved, "That this meeting request from Mr. Coombs a distinct pledge, in writing, to the Chairmar, that in future he will not practise homoeopathy; and that he will discontinue using the M.D. from a Homœopathic College."

Resolved, "That it is the opinion of this meeting that mem. bers of the profession should refuse to meet in consultation any one who meots in consultation with homcopathic practitioners."

Mr. Thurnall gtated that some medical men in the town, and their wives, were in the habit of calling upon new-comers solely for the purpose of securing them as patients.

Dr. BARKER mentioned some facts showing a disregard of the ordinary rules of medical ethics on the part of some practitioners in the town.

Mr. Sharpin and Dr. Prior thought any resolution upon these facts was uncalled for.

Resolved,_"That in the opinion of this meeting, the practice of medical men, or their wives, calling upon new-comers in the town or neighbourhood, with the view of either directly or indirectly securing them as patients, is derogatory to the profession; and that the present meeting earnestly recommends that in future the strictest regard to professional etiquette should on all occasions be observed by the members of the profession."

Mr. CARTER having alluded to the fact that one practitioner was present who, as a Licentiate of the Faculty of Physicians and Surgeons of Glasgow, used the title of M.D., and that such license does not give a right to the use of such title, Mr. Hacon at once pledged himself not to use the title of M.D. for the future.

Dr. BARKER said that sufficient had come under the notice of the meeting to show the necessity of a society which should take cognizance of any professional irregularities; in fact of a court medical. He proposed that a Bedford Medico-Ethical Society should be established, to consist of a president, a secretary, and three members of committee. The president and secretary to be chosen annually, and one member of the com mittee to retire annually in rotation. If any member of the profession in the town or county had any reason to complain of the conduct of any other member, he should communicate with the secretary, who should call a meeting of the committee. If the committee deemed the alleged charge of sufficient impor. tance, a meeting of the entire profession to be called for the purpose of settling the matter in dispute.

Resolved, - "That a Bedford Medico-Ethical Society be now established, and that Mr. Couchman be elected president, $\mathbf{M r}$ Carter secretary, and Dr. Wharton, Mr. Thurnall, and Mr. C. Robinsou the members of the committee."

At this stage of the proceedings Mr. Coombs entered the room.

The Chatrman explained to Mr. Coombs the object of the meeting, and disclaiming on the part of himself and of every member present any personal feeling, or any other motive than the purest desire to uphold the honour of the profession, read to him the first resolution which had been passed.

Mr. Coombs expressed his willingness to give the required pledge, in writing, to the Chairman as far as the practise of homoopathy is concerned, but refused to discontinue the use of the M.D. degree.

Mr. Couchman having been urgently called away, Dr. Barker was requested to take the chair.

Resolved, - " That this meeting will not recognise $\mathrm{Mr}$. Coombs' repudiation of homcopathy unless he at the same time repudiates the degree of M.D. obtained from a homœopathic university."

Mr. Coombs was urged in feeling terms by the chairman, and by several members of the meeting, to give up the use of the homcopathic M.D.; but Mr. Coombs still maintaining that he had made all necessary concessions, the following resolution was unanimously, although relunctantly, passed :-

Resolved, - "That this meeting congratulate Mr. Coombs on his repudiation of homœopathy as a practice; but regret that in consequence of his not agreeing to resign his title of M.D. obtained from a homcepathic college, they cannot consent to meet him in consultation."

In consequence of Mr. Coombs' decision,

liesolved,_- "That the name of Dr. Prior be substituted for that of Dr. Wharton in the committee of the Bedford MedicoEthical Society."

Resolved, "That a copy of these resolutions be forwarded. for publication in the medical journals and the local papers."

Resolved,-_" "That the thanks of the meeting be given to the Chairman."

Robert Cotchman, Chairman.

Geo. Pocock Goldsmith, Secretary.

\section{érotespondemer.}

"Audi alteram partem."

MEDICAL FEES.

To the Editor of THe LANCET.

SIR,-In reply to your question whether or no I " endorse the tariff" of $£ 25$ for a whole day's professional service, irrespectively of the distance travelled, it will be sufficient to say that I am not and never was a party to such an arrangement.

My own feeling is opposed to a fixed rate of charge for either country visits or operations, since the service so afforded is the same, however much the circumstances of patients may vary. The tradesman can put a value on his commodities, and limit their distribution to those who are able to comply with the terms of sale. But anyone who practices physic or surgery as a profession, should endeavour to render the means of relief which he possesses, so far as possible, available to those who require them, and with this view place the liberality of the rich to the credit of the poor.

Rutland·street, Edinburgh, July, 1863.

$$
\text { I am, Sir, yours, \&c., }
$$

\section{To the Editor of THE LanceT.}

SIR, - In reference to the correspondence between Dr. Vose, of Liverpool, and the executors of the late Mr. Grant, ani- 
madverted npon in your last number, I feel called upon to state-

1. That I knew nothing whatever of this case and corre. spondence, till a printed copy of the latter reached me a few days ago by post.

2. That the introduction of my name in the correspondence has been not only without my authority but without my knowledge.

3. That the "tariff" to which I alluded in my private correspondence with Sir Thomas Gladstone, in 1852, had reference to visits morerately "distant" from town, and would not apply to such special services as those of Dr. Vose in the case now in question.

I am, Sir, your obedient servant,

Charlotte-square, Edinburgh, July, 1863. JAS. MHIER.

\section{BARON LARREY AND COLONEL WAYMOUTH.} To the Editor of THE LANCET.

SrR,-Having seen in your paper of the 4 th inst. the "anecdote of Baron Larrey" and Colonel Weymouth-(? Waymouth) -I beg, in justice to a brave officer, you will kindly give the same publicity to the true statement as you have done to the imputation that Colonel Waymouth was impelled to charge the French by any other cause than the command of his superior officer and "his own bravers."

The charge of the heavy cavalry at Waterloo is well known. As far as my uncle was concerned this is the case :-The Second Life Guards, in which was Lieutenant Samuel Waymouth, were drealfully cut up. My uncle cooly and deliberately rorie at the head of his troops, yoing into action with upwards of fifty men, but when he and they bad cut through the French, he found himself with only a few troops-I think seven was the number. He tried to make his way back to the British lines, but was taken prisoner. His corporal-there are not ser geants in the Life Guards-was smashed by a canon ball, and the lieutenant was completely covered with the brains and blood of his faithful companion. I have heard my father often relate the tale, and you may depend on the truth of my state ment.

I should not have troubled you with this communication, did I not feel sure that you wonld not willingly allow a slur to be cast on a brave man.

I remain, Sir, your obedient servant,

Lower Park-road, Peckham, July, 1863. SAMUEx WAYmooth.

\section{DR. HUGHES BEN NETT'S LECTURES.}

$$
\text { To the Editor of THR LANCHT. }
$$

SrR, - 1 am sorry to be obliged to admit that Dr. Bennett's reply to my last leaves my mind more confused than ever in what manner his "Molecular Theory" can explain the origin of the vibriones. It is evident, however, that he will not allow them to have sprung from pre-existing "cells." I suppose he means from pre-existing masses of matter, as I particularly qualified the term "cell." If therefore they did not spring from anything pre-existing, they must of necessity have arisen from the elenents of the fluid in which they are found, which, as I remark in my former let ter, is nothing more nor less than by " spontaneous generation." I am obliged therefore to end furiher arguments on this point, for however free I may be to accept this cloctrine when proved, I must confess I am scarcely advunced enough yet to receive it. I find I was mistaken in supposing Dr. Bennett had not believed in it.

I cannot agree with the limiting law laid down by Dr. Bennett, as he thinks I shall, that a vegetable cell cannot grow at the sane time that it is subdividing, either in the linear or in the quaternery direction; on the contrary, I am perfectly certain that it can do sn frotn numerous observations on all sorts of vegetable cells. Nor do I see anything at all inconsistent with our physiological knowledge in the fact; but were it so, I can only say our knowledge was not in accordance with the fact. The process of subilvision by segmentation is merely a variety of the vegetable process; there is nothing to my mind in one process subversive of the other, Enlargement of bulk and the simultaneous division of it constantly takes place; the subdivision growing at the same time that separating process is being completed. Those who have observed the mode of growth of the gonidia of the algæ, lichens, mosses, and of oscillatoria, will I am sure agree with me. This is the mode of growth of the fronds of the lower plants, and is probably the rule in alls vegetative life. I might refer to the accurate and careful do scription of the growth of the higher cryptogamia by Hofmeister (Ray Soc., 1862), and particularly to Braur's Rejuvene. scence in Nature, p. 249 (Ray Soc., 1853), and many other works treating of cell growth.

Dr. Bennett will remember that $I$ did not attempt to bring: the whole proofs and reasonings which render it certain that the unimpregnated uterus has contractile power. I can lay no claim to the opinion as original.

I am, Sir, your obedient servant,

J. Braxton Hrcks, M.D., F.R.S.

St. Thomas's-street, London-bridge, July, 1863.

\section{CHOLERA IN INDIA.}

\section{To the Editor of The Lancet.}

Sin,--With reference to your review of the Report on Cholera in India in 1861, which appeared in the LANCET of the 27th June, permit me to state that during and since the war in the Crimea I have again and again called the attention of the Army Medical Department, that of the War Office, that of the Horse Guards, and that of the India Office, to the facts, that cholera has never been studied scientifically by the Army Medical Department, that they are unacquainted with the pathology of cholera, and that the medical treatment adopted by them is contra-indicated by the pathology of cholera, and assists cholera to destroy life. The receipt of my letters was acknowledged, but nothing was done.

In the above Report which you have noticed in your number of the 27th ult., it is admitted that cholera has never been scientifically studied in India. At paragraph 427 of that $R e$. port it can be seen that the Army Medical lyepartment were not acquainted with the pathology of cholera ; and as to methods of cure adopted for this disease, it appears by paragraph 278 of that Report, that the mortality is at the rate of 80,90 , or 100 per cent. - "a mortality," says Dr. Mountjoy in that Report, "which in all probability would not occur if nature were left to herself to battle with this disease."

As cholera has again broken out at Benares, in the interest of humanity I have written to the Minister of War, placing. myself at his disposal, to appear before any committeee his lordship may please to appoint, and to demonstrate to that committee-

1. That the Army Medical Department have never studied cholera scientifically.

2. That they are not acquainted with the pathology of cholera.

3. That the medical treatment adopted by the Army Medical Department is contra-indicated by the pathology of the disease, and assists the disease to destroy live.

$$
\text { I remain, Sir, your obedient servant, }
$$

$$
\text { D. MaclovghurN, M.D., }
$$

Bruton-street, Berkeley-square, July, 1863 Member of UGHLIN, M.D.,

P.S. - Since writing the above I have been informed by the Military Secretary that the Field-Marshal, his Royal Highness the Duke of Cambrioge, has been pleased to refer my offer to appear before a committee, as stated above, to Dr. Gibson, the Director-General of the Medical Department, for his opinion. Although Dr. Gibson has twice prejudged the question at issue, yet as he now sees by the Official Report on the Outbreak of Cholera in India in 1861 that he was in error, it is possible that he will not a third time mislead the authorities and prevent an inquiry which ought to have taken place forty-six years ago, and which would have saved thousands and thousands, if not millions, from untimely graves.

\section{EXCISION OF THE HUMERUS. To the Editor of The LANCET.}

SIR,-I am requested by Dr. Gilfillan, of Brooklyn, New Yor $k$, to inquire of you whether you are aware of any recorded instances of excision of the humerus. He has successfully removed the whole shaft in a case of compound comminuted frac. ture, and with the best results. He has not been able to find a similar case in the records of surgery.

I am, Sir, your obedient servant, George SEEARER, M.D.

Windsor-street, Toxteth-park, Liverpool, July, 1863

** No such case has, we believe, ever been recorded. A good history would be exceedingiy interesting. - ED. I. 